Jurnal Aksi Reformasi Government Dalam Demokrasi

Volume 7- Nomor 2, Desember 2019

DOI: $10.34010 /$ agregasi.v7i2.2314

Available online at: https://ojs.unikom.ac.id/index.php/agregasi

\title{
PERAN KECAMATAN BANDUNG WETAN DALAM PROGRAM INOVASI PEMBERDAYAAN PEMBANGUNAN KEWILAYAHAN (PIPPK)
}

\author{
Nova Suryani 1), Bagus Sugiharto 2), Dita Anggraeni ${ }^{3)}$ \\ Progam Studi Manajemen, Universitas Jenderal Achmad Yani , Jl. Terusan Jend. Sudirman, \\ Cibeber, Kota Cimahi, Jawa Barat, 40531, Indonesia. \\ Email: novasuryanii@gmail.com ${ }^{1)}$, bjsugiharto.bs@gmail.com ${ }^{2)}$, dita.anggraeni86@gmail.com ${ }^{3)}$
}

\begin{abstract}
Abstrak
Tujuan penelitian ini adalah untuk mengetahui peran dari Kecamatan Bandung Wetan dalam melaksanakan program Inovasi Pemberdayaan Pembangunan Kewilayahan (PIPPK). Metode yang dilakukan dalam penelitian ini menggunakan metode deskriptif dengan pendekatan kualitatif. Teknik pengumpulan data berupa studi pustaka, observasi tidak langsung dan wawancara terhadap informan dan dokumentasi. Hasil penelitian diketahui bahwa Pemerintah Kota Bandung melalui Program Inovasi Pemberdayaan Pembangunan Kewilayahan (PIPPK) dilaksanakan dengan tujuan untuk meningkatkan keberdayaan masyarakat melalui pemberdayaan pembangunan di kewilayahan. Kecamatan Bandung Wetan menjadi salah satu kecamatan yang ikut berpartisipasi dalam mewujudkan program pemerintah tersebut. Dalam pelaksanaannya, peran kecamatan melalui Program Inovasi Pemberdayaan Pembangunan Kewilayahan (PIPPK) belum tercapai secara maksimal karena terkendala berbagai hal.
\end{abstract}

Kata Kunci: Pemberdayaan Masyarakat, PIPPK, Pembangunan, Camat.

\section{THE ROLE OF BANDUNG WETAN SUB-DISTRICT IN EMPOWERING OF REGIONAL DEVELOPMENT INNOVATION PROGRAM (PIPPK)}

\begin{abstract}
The purpose of this study was to determine the role of Bandung Wetan District in implementing innovation program of Regional Development Empowerment (PIPPK). The method used in this study is descriptive method with a qualitative approach. Data collection techniques in the form of indirect observation and interviews with informants. The results of the study revealed that the Government of the City of Bandung through the Empowerment of Regional Development Empowerment Innovation Program (PIPPK) was implemented with the aim of increasing community empowerment through empowering development in the region. Bandung Wetan District is one of the sub-districts that participated in realizing the government program. In its implementation, the role of the sub-district through the Empowerment of Regional Development Empowerment Innovation Program (PIPPK) has not been maximally reached because of various constraints.
\end{abstract}

Keywords: Community Empowerment, PIPPK, Development, Camat. 


\section{PENDAHULUAN}

Kecamatan sebagaimana diatur Dalam Peraturan Pemerintah Nomor 17 tahun 2018 tentang Kecamatan, merupakan sebuah perangkat daerah kabupaten/kota sekaligus penyelenggara pemerintahan umum. Undang-undang Nomor 23 Tahun 2014 tentang Pemerintahan Daerah, menjelaskan bahwa kecamatan tidak lagi merupakan satuan wilayah kekuasaan pemerintahan, melainkan sebagai satuan wilayah kerja atau pelayanan. Berdasarkan peraturan perundang-undangan tersebut, setiap pemerintah daerah baik itu kabupaten maupun kota di seluruh Indonesia berlomba-lomba untuk membuat berbagai pengaturan yang pada akhirnya dinilai mengganggu aktifitas masyarakat umum dan tentu saja dapat berpengaruh terhadap pemberdayaan kewilayahan dalam suatu wilayah.

Berdasarkan Peraturan Pemerintah nomor 38 Tahun 2017 tentang inovasi daerah, Pemerintah Daerah termasuk pemerintah kabupaten dan kota serta perangkat didalamnya dituntut untuk dapat melakukan inovasi. Inovasi tersebut dilaksanakan dalam setiap kegiatan penyelenggaraan pemerintahan. Inovasi daerah berarti bahwa semua bentuk pembaharuan dilakukan dalam penyelenggaraan Pemerintahan Daerah.

Saat ini, status kecamatan merupakan perangkat daerah kabupaten/kota yang setara dengan dinas dan lembaga teknis daerah. Dijelaskan bahwa pelimpahan sebagian kewenangan dari bupati/wali kota kepada camat dilaksanakan untuk mengefektifkan penyelenggaraan pemerintahan daerah terutama di Kecamatan. Selain itu, untuk mengoptimalkan pelayanan kepada masyarakat di Kecamatan sebagai perangkat daerah yang berhubungan langsung dengan masyarakat.

Pemerintah Kota Bandung pada masa pemerintahan Ridwan Kamil mengeluarkan program unggulan yaitu Program Inovasi Pemberdayaan Pembangunan Kewilayahan (PIPPK). Program ini dalam penyelenggaraannya diharapkan mampu menggerakakan kembali keaktifan dari masyarakat terutama dalam membangun wilayahnya sendiri. Hal tersebut sejalan dengan adanya asas keterbukaan. PIPPK menjadi salah satu solusi ketika masyarakat memiliki masalah yang tidak diakomodasi dalam Musrenbang.

Program PIPPK didalamnya terdapat semangat kebersamaan, desentralisasi, dan mendorong kemampuan leadership aparatur sebagaimana senada dengan tujuan Bandung Empowerment City. Sasaran dari pelaksanaan program PIPPK adalah mewujudkan komitmen dan konsistensi baik dalam perencanaan maupun pelaksanaan kegiatan pembangunan pada masing-masing kelurahan di Kecamatan yang berorientasi kepada pembangunan masyarakat setempat dengan pendekatan berbagai inovasi, desentralisasi dan kolaborasi dengan kebutuhan serta kemampuan masyarakat Kelurahan yang didukung sistem pendampingan, pengawasan dan pengendalian yang efektif.(Alia \& Maulana, 2019) 
Dalam penyelenggaraanya PIPPK mengalami beberapa kendala diantaranya adalah di wilayah yang letaknya di pusat kota respons masyarakat terahadap Program Innovasi Pembangunan dan Pemberdayaan Kewilayahan (PIPPK) belum optimal, bergantung pada aparat kewilayahannya apakah bisa mengkoordinir masyarakatnya atau tidak.(Alia \& Maulana, 2019)

Kecamatan Bandung Wetan merupakan salah satu dari 30 Kecamatan yang berada di wilayah Kota Bandung. Kecamatan Bandung Wetan menjadi salah satu bagian dari wilayah Cibeunying Kota Bandung dengan memiliki luas tanah sebesar 339 Ha. (Bandung, 2015) Kecamatan Bandung Wetan terletak di pusat Kota Bandung, merupakan daerah yang sebagian besar didominasi oleh kawasan perdagangan, restoran, hotel dan sektor jasa dan sebagian kecil terdapat pemukiman penduduk. Secara administratif Kecamatan Bandung Wetan dibatasi oleh:

1. Bagian Selatan: Kecamatan Sumur Bandung

2. Bagian Utara: Kecamatan Coblong

3. Bagian Timur: Kecamatan Cibeunying

4. Bagian Barat: Kecamatan Sukajadi

Secara geografis Kecamatan Bandung Wetan memiliki bentuk wilayah datar/ berombak sebesar $100 \%$ dari total keseluruhan luas wilayah. Ditinjau dari sudut ketinggian tanah, Kecamatan Bandung Wetan berada pada ketinggian $675 \mathrm{~m}$ diatas permukaan air laut. Suhu maksimum dan minimum di Kecamatan Bandung Wetan berkisar 28c, sedangkan dilihat dari segi hujan berkisar - $\mathrm{mm} /$ th dan jumlah hari dengan curah hujan yang terbanyak sebesar 45 hari.

Kecamatan mempunyai tugas pokok melaksanakan sebagian kewenangan pemerintahan yang dilimpahkan Walikota kepada Camat untuk menangani sebagian urusan otonomi daerah. Adapun aktivitas yang dilakukan di Kecamatan Bandung Wetan yaitu sebagai berikut:

1) Mengkoordinasikan kegiatan pemberdayaan masyarakat.

2) Mengkoordinasikan upaya penyelenggaraan ketentraman dan ketertiban umum.

3) Mengkoordinasikan penerapan dan penegakan peraturan perundang-undangan.

4) Mengkoordinasikan pemerliharaan prasarana dan fasilitas pelayanan umum.

5) Mengkoordinasikan penyelenggaraan pemerintahan di tingkat kecamatan.

6) Membina penyelenggaraan pemerintahan kelurahan.

7) Melaksanakan pelayanan ketatausahaan kecamatan

Program PIPPK menjadi salah satu fokus dalam pengembangan kewilayahan sebagai bagian desentralisasi kewilayahan di kecamatan. Hal tersebut dilaksanakan mengingat kecamatan memiliki wilayah yang cukup luas dengan jarak gestur politik dan jumlah penduduk serta potensi yang dimiliki. Pemerintah kecamatan 
memiliki tiga fungsi utama, yaitu model program sistem pelayanan publik yang efektif dan efisien untuk senantiasa mengedepankan kesejahteraan masyarakat, sebagai arena pengembangan kehidupan ekonomi kerakyatan dan sebagai arena pengembangan demokrasi di tingkat kota untuk pengambilan keputusan politik.

Kecamatan Bandung wetan letaknya yang berada di pusat Kota Bandung menjadikan Kecamatan Bandung Wetan tumbuh subur dan pembangunan yang cukup banyak. Akan tetapi, Pelaksanaan Program Inovasi Pembangunan dan Pemberdayaan Kewilayahan (PIPPK) di Bandung Wetan masih perlu disosialisasikan kepada masyarakat. Hal tersebut dikarenakan masih banyaknya kendala dimasyarakat di mana masyarakat tidak memiliki pemahaman mengenai anggaran PIPPK. Tujuan dari penelitian ini adalah mengetahui sejauh mana peran kecamatan dalam penyelenggaraan PIPPK di Kecamatan Bandung Wetan.

\section{METODE}

Pada penelitian ini menggunakan metode deskriptif dengan pendekatan kualitatif. Penelitian ini berlokasi di Kantor Kecamatan Bandung Wetan yang beralamat di JL. Taman Sari No. 49 Lebak Siliwangi, Coblong Kota Bandung, Jawa Barat 40132.

Adapun teknik pengumpulan data yang dilakukan dalam penelitian ini adalah: Studi Pustaka, Studi Lapangan berupa observasi non partisipan dan Wawancara serta dokumentasi.

Adapun teknik analisis data yang digunakan oleh peneliti yaitu reduksi data, Penyajian data dan penarikan kesimpulan.

\section{HASIL DAN PEMBAHASAN}

Kecamatan merupakan perangkat daerah kabupaten/kota sebagai pelaksana teknis kewilayahan yang mempunyai wilayah kerja tertentu dan dipimpin oleh camat. Sedangkan Camat berkedudukan di bawah dan bertanggung jawab kepada bupati/wali kota melalui sekretaris daerah.(Haluana \& Mustafa, 2016)

Penyelenggaraan kecamatan dalam pengaturannya sudah diatur dalam Peraturan Pemerintah secara legalistic baik dari sisi pembentukan, kedudukan, tugas dan fungsinya.

Camat sebagai perangkat daerah mendapatkan pelimpahan kewenangan. Adapun bentuk pelimpahan kewenangan pemerintahan untuk menangani sebagian urusan otonomi daerah meliputi aspek :
a. Perizinan
b. Rekomendasi
c. Koordinasi
d. Pembinaan
e. Pengawasan
f. Fasilitasi
g. Penetapan
h. Penyelenggaraan dan
i. Kewenangan lain yang dilimpahkan(Hamidah, 2012) 
Camat dalam menjalankan tugasnya dibantu oleh perangkat kecamatan dan bertanggung jawab kepada bupati/wali kota melalui sekretaris daerah kabupaten/kota.

Peran Kecamatan untuk masyarakat adalah kecamatan berupaya untuk meningkatkan kesejahteraan masyarakat melalui pemberdayaan yang berkelanjutan, meningkatkan peran masyarakat dalam perencanaan dan pelaksanaan pembangunan yang partisipatif, membantu masyarakat untuk memenuhi kelengkapan administrasi Negara, seperti pembuatan KTP, KK, AKTE, hingga Surat Izin Usaha.

Proses pemberdayaan masyarakat mengandung 2 (dua) kecenderungan yaitu: yang pertama adalah proses pemberdayaan yang menekankan kepada proses memberikan atau mengalihkan sebagian kekuasaan, kekuatan, atau kemampuan kepada masyarakat, agar individu menjadi lebih berdaya. Proses ini dapat dilengkapi pula dengan upaya membangun asset material guna mendukung pembangunan kemandirian mereka melalui organisasi kecenderungan ini disebut kecenderungan primer dari makna pemberdayaan. Kecenderungan yang kedua atau kecenderungan sekunder adalah mekankan pada proses menstimutasi, mendorong, atau memotivasi individu agar mempunyai kemampuan atau keberdayaan untuk menentukan apa yang menjadi pilihan hidupnya melalui proses dialog. Menurut (Pranarka dan Moeljarto, 1996:56-57),
Pelaksanaan pemberdayaan masyarakat oleh kecamatan dan terutama dalam rangka penyelenggaraan otonomi daerah maka dengan merujuk pada Peraturan Walikota Nomor 436 Tahun 2015 Kota Bandung yakni Program Inovasi Pembangunan dan Pemberdayaan Kewilayahan (PIPPK) yang dinilai sukses menghadirkan perubahan yang merata di masyarakat.

Program Inovasi Pembangunan dan Pemberdayaan Kewilayahan yang (PIPPK) sendiri adalah "Program Pemberdayaan Kewilayahan yang meliputi kegiatan pemberdayaan Lingkup RW, pemberdayaan lingkup PKK, pemberdayaan lingkup Karang Taruna dan pemberdayaan lingkup LPM".(Peraturan Walikota Bandung Nomor 015 Tahun 2019 Tentang Pedoman Teknis Pelaksanaan Program Inovasi Pembangunan dan Pemberdayaan Kewilayahan, 2019)

Tidak dapat dipungkiri bahwa dalam pelaksanaannya masih banyak kendala yang dihadapi. Diantaranya adalah kurangnya minat masyarakat untuk berpartisipasi terhadap program program Wali Kota. Hal tersebut berakibat pada program yang tidak terealisasi secara maksimal.

"Banyak aspek yang harus dibenahi, dari mulai merubah mindset. Mulai dari aparat kewilayahan, LPM, RT, RW ini belum sama. Oleh karena itu saya dan Pak Wali waktu tahun 2015, targetnya penyerapan (anggaran) yang bagus.Tentu 2016 ini diharapkan bukan hanya penyerapannya saja harus di 
perhatikan,

tapi

manfaat

pelaksanaannya harus tepat sasaran," kata Wakil Wali Kota Bandung Oded M. Danial. (http://www.pikiranrakyat.com/bandungraya/2016/11/10/pelaksanaan-pippktak- sederhana-384391)(Heri, Caesar, \& Zakaria, 2017).

Supriatna (200: 171) menjelaskan bahwa faktor utama yang berpengaruh terhadap keberhasilan pemberdayaan masyarakat yaitu: perilaku birokasi pemerintahan, dukungan birokrasi pemerintahan lokal, fungsi birokasi pemerintahan lokal terhadap pembangunan sosial, tingkat pendidikan masyarakat, serta akses-akses masyarakat terhadap informasi program.

Selain itu, faktor pendukung pemberdayaan masyarakat adalah partisipasi masyarakat (Supriatna, 2000:148). Dengan mengikutsertakan atau bahkan dilaksanakan masyarakat atau kelompok yang menjadi sasaran yang akan dibantu (target group), maka proses pemberdayaan akan lebih berjalan dengan baik, karena hal ini sekaligus dapat meningkatkan daya (power) dari masyarakat. Dengan adanya keterlibatan (partisipasi) masyarakat tersebut, berarti masyarakat telah memiliki kapasitas dan rasa peracaya diri (self confidence) untuk berpartisipasi dan mempengaruhi kehidupan dalam komunitas masyarakat itu sendiri.(Heri et al., 2017)

Program PIPPK di Kota Bandung telah bergulir sejak 2015 cukup signifikan dalam pemerataan pembangunan. PIPPK tahun 2018 yang telah banyak melahirkan infrastruktur baru di setiap wilayah. Ada $588.701 \mathrm{~m} 2$ jalan lingkungan yang diperbaiki, 106 unit Rumah Tidak Layak Huni (Rutilahu) yang direhabilitasi, dan ada 339 unit WC umum yang dibangun untuk kepentingan sanitasi.

Kecamatan Bandung Wetan sendiri memiliki 3 Kelurahan yaitu Kelurahan Cihapit, Kelurahan Citarum, Kelurahan Tamansari Di wilayah Kecamatan Bandung Wetan. Pada masing-masing kelurahan sistem pencairan anggaran PIPPK tidak dapat dicairkan dalam satu waktu atau dengan kata lain dicairkan secara bertahap yaitu dalam 3 bulan sekali atau per triwulan. Sistem pencairan anggaran PIPPK itu sendiri di Kecamatan Bandung Wetan dicairkan melalui GU (Ganti Uang), TU (Tambah Uang) dan LS (Langsung). Sistem pencairan PIPPK tersebut digunakan sesuai dengan kondisi pada kegiatan yang akan dilakukan oleh karang taruna dari masing-masing kelurahan.

PIPPK dilaksanakan untuk lebih mengoptimalkan aspirasi masyarakat serta dapat mensosialisasikan program tersebut dengan lebih masif lagi. Bahkan beberapa dari masyarakat belum begitu paham masalah Kodrek (Kode Rekening).

Maksud dilaksanakan PIPPK adalah untuk meningkatkan tugas, peran, dan fungsi apparat kewilayahan beserta seluruh stakeholder Lembaga Kemasyarakatan Kelurahan dalam rangka percepatan pelaksanaan pembangunan melalui pengembangan pemberdayaan masyarakat.

Pelaksana PIPPK adalah warga masyarakat yang tergabung dalam 
Kelurahan melalui Kelompok Masyarakat yang dibentuk berdasarkan kebutuhan masyarakat secara mufakat, sebagai penunjang pelaksanaan kegiatan PIPPK dan didukung oleh berbagai pihak meliputi kelompok ahli, dunia usaha dan masyarakat luas.(Peraturan Walikota Bandung Nomor 015 Tahun 2019 Tentang Pedoman Teknis Pelaksanaan Program Inovasi Pembangunan dan Pemberdayaan Kewilayahan, 2019)

Tujuan dari pelaksanaan PIPPK adalah untuk mewujudkan sinergitas kinerja aparatur kewilayahan dengan Lembaga Kemasyarakatan Kelurahan yang berbasis pada pemberdayaan masyarakat.(Peraturan Walikota Bandung Nomor 015 Tahun 2019 Tentang Pedoman Teknis Pelaksanaan Program Inovasi Pembangunan dan Pemberdayaan Kewilayahan, 2019)

Mengenai dana PIPPK digunakan untuk merehabilitasi 491 unit kantor lembaga kemasyarakatan, memperbaiki $31.107 \mathrm{~m} 2$ gorong-gorong dan saluran air, serta membangun 26 unit sumur resapan. Warga juga secara mandiri membangun 606 unit gapura RW, memelihara 58 unit taman dan urban farming, memperbaiki 54 unit rumah ibadah, dan menyalakan 154 unit penerangan jalan lingkungan.(Heri et al., 2017)

Tak hanya di bidang infrastruktur, dana PIPPK juga digunakan untuk kegiatan sosial dan ekonomi, seperti kegiatan keagamaan, lomba-lomba, pelatihan, pembinaan, dan sosialisasi program pemerintah. Semua kegiatan tersebut menghabiskan dana Rp142,23 miliar dari pagu anggaran sebesar Rp154,45 miliar di tahun 2018.

Adanya prinsip-prinsip otonomi daerah sejalan dengan semangat PIPPK untuk mendesentralisasikan pembangunan di wilayah-wilayah. Lurah dan camat di wilayah Kota Bandung sebagaimana disampaikan oleh Walikota Bandung Oded M. Daniel diberi kewenangan untuk melaksanakan inovasi pembangunan di wilayahnya.

Dalam keterangannya, walikota mengatakan, tiga pilar Kota Bandung, yakni inovasi, kolaborasi, dan desentralisasi, yang terus ditanamkan melalui berbagai program diharapkan mampu mewujudkan visi Kota Bandung menjadi kota yang unggul, nyaman, sejahtera, dan agamis. Melalui 3 pilar tersebut Kota Bandung sudah berupaya mengimplementasikan semangat otonomi Daerah ini.

Inti dari program PIPPK adalah Mensejahterakan masyarakat. PIPPK mengeluarkan dana ke 4 lembaga sebanyak 100 juta. 4 Lembaga itu antara lain : RW ( Rukun Warga), Karang Taruna, PKK, dan LPM. Jadi jika ada kegiatan / program (contoh program unggulan : Acara 17 Agustus,atau pelatihan masak bagi ibu - ibu) dana yg didapatkan adalah dari PIPPK. Tetapi Saat ini minat dari masyarakat kurang karena alasan yg disebutkan di atas.

Jenis kegiatan dalam PIPPK berbasis Pemberdayaan Masyarakat sebagai berikut:

a. fasilitasi pemberdayaan lingkup RW;

b. fasilitasi pemberdayaan lingkup PKK; 
c. fasilitasi pemberdayaan lingkup Karang Taruna; dan

d. fasilitasi pemberdayaan lingkup LPM. Untuk mewujudkan harapanharapan tersebut pihak kelurahan melakukan upaya-upaya agar proses pemberdayaan melalui PIPPK berjalan dengan baik, yaitu: Pertama, sosialisai PIPPK merupakan upaya pertama sebelum melaksanakan suatu program atau kegiatan, hal ini bertujuan untuk memberikan pemahaman lebih jelas tentang apa yanga akan kita laksanakan. Di sosialisasi inilah pihak kelurahan akan menjelaskan tentang PIPPK tersebut lebih dalam bagaimana petunjuk dan teknis yang harus dilakukan dalam menjalankan program tersebut mulai dari dasar hukum, tatacara sampai ke proses pelaksanaannya. Sosialisai dilakukan kepada seluruh aparat kelurahan dan mengundang ketua RW, LPM, PKK dan Karang Taruna serta beberapa tokoh masyarakat, karena program ini ditujukan untuk empat lembaga kelurahan tersebut. Sosialisasi ini bertujuan agar program tersebut dapat dipahami lebih jelas sebelum nantinya akan di sosialisasikan kembali kepada seluruh masyarakat maupun anggota di kelembagaannya.(Muhyidin, Sumpena, \& Azis, 2017)

Kedua, rembug warga dan rapat anggota merupakan upaya selanjutnya setelah melakukan sosialisai yaitu mengadakan rembug warga dan rapat anggota, hal ini sangat penting sekali agar seluruh masyarakat atau anggota mengetahui dengan jelas apa itu PIPPK. Dalam rembug warga dan rapat anggota ini masyarakat sangat antusias dalam memeberikan argument dan menanggapi kegiatan tersebut, selain itu di sosialisasikan kembali apa itu PIPPK kepada seluruh masyarakat dan anggota dengan lebih jelas serta mulai memusyawarahkan kepada masyarakat apa saja kegiatan yang akan dilaksanakan sesuai kesepakatan, oleh karena itu rembug warga dan rapat anggota ini bentuk dari keterbukaan antara aparat pemerintah terhadap masyarakat, sehingga masyarakat percaya terhadap birokrasi pemerintah. Warga cukup antusias terhadap program yang diupayakan oleh pemkot Bandung, seperti banyaknya warga yang aktif dalam menanggapi penjelasan dari RW perihal PIPPK sebab warga melihat adanya harapan akan kesejahteraan di masyarakat.

Ketiga, perencanaan program untuk melaksanakan kegiatan rembug warga maka upaya selanjutnya yaitu perencanaan program, merencanakan kegiatan apa saja yang akan dilaksanakan baik itu dalam bidang ekonomi, sosial budaya, lingkungan sesuai dengan bidang pemberdayaan PIPPK, kemudian dibuat menjadi sebuah proposal pengajuan kegaiatan, proposal tersebut nanti akan di musrenbangkan di kelurahan sebelum diserahkan kepada pemerintah kota Bandung (pemkot Bandung) melalui pihak kelurahan dan kecamatan. Tahap selanjutnya yaitu menunggu konfirmasi dari pemkot Bandung, setelah adanya konfirmasi tentang kegiatan tersebut barulah program tersebut dapat dilaksanakan. Namun dalam pelaksanaan 
tidak sepenuhnya dilakukan oleh masyarakat sebab harus melibatkan pihak ketiga. Pihak ketiga adalah orang yang diperintahkan oleh kelurahan untuk menangani atau mengerjakan PIPPK dalam proses pembangunan infrastruktur atau bisa disebut pemborong dalam pengerjaannya, tanpa adanya melibatkan masyarakat.

Keempat, pengawasan dalam upaya selanjutnya yaitu pengawasan, sebenarnya pengawasan ini sudah dilakukan bersamaan dengan pelaksanaan kegiatan, pengawas disini yaitu beberapa orang dari pemerintahan dan seluruh masyarakat. Tugas mereka yaitu mengawasi segala bentuk kegiatan atau program apa saja yang sedang dilaksanakan. Mereka yang nantinya akan melaporkan segala bentuk ataupun kejadian yang sesungguhnya dilapanganan. Kelima, evaluasi merupakan upaya yang terakhir yaitu evaluasi, yang bisa diartikan juga sebagai proses penilaian, evaluasi juga sebagai proses pengukuran akan efektivitas kegiatan yang telah dilaksakan apakah kegiatan itu berjalan dengan baik atau buruk. Setelah mendapatkan data itu barulah masyarakat bisa merencanakan kembali kegaiatan apa yang harus dibenahi atau diperbaiki agar mencapai tujuan yang lebih maksimal. (Muhyidin et al., 2017).

\section{SIMPULAN DAN SARAN}

\section{Simpulan}

Kecamatan mempunyai peran yang sangat penting dalam rangka pembinaan dan pengawasan penyelenggaran program inovasi pembangunan kewilayahan. Setiap penyelenggaraann PIPPK pengawasan dilakukan oleh kecamatan sebagai pihak yang bertanggungjawab dalam pelaksanaan PIPPK di kelurahan masingmasing.

Kecamatan Bandung Wetan yang merupakan wilayah yang berada di pusat Kota Bandung memiliki anggaran yang cukup tinggi luntuk pelaksanaan program PIPPK. Akan tetapi dalam pelaksanaanya masing terdapat beberapa hambatan.

Akan tetapi sampai saat ini masih dinilai efektif dalam upaya pemerintah memberikan pemberdayaan masyarakat yang langsung dirasakan manfaatnya oleh masyaraka di wilayah Kecamatan Bandung Wetan.

Untuk itu diperlukan peningkatan pemahaman, pengetahuan dan kemampuan lintas sektor/lintas program serta masyarakat, kegiatan pembinaan kader PKK, LPM dan Karang Taruna menjadi wahana yang menjembatani antara kebutuhan program dan proses kemandirian masyarakat. Dalam pemberdayaan masyarakat yang terpenting adalah bagaimana menjadikan masyarakat pada posisi pelaku pembangunan yang aktif dan bukan penerima pasif oleh karena itu salah satu penyebab kurangnya penyerapan anggaran kelurahan merdeka dibanding dengan kelurahan cihapit dan 
diperlukannya diseminasi yang dilakukan dengan baik.(Alia \& Maulana, 2019)

\section{Saran}

1. Kecamatan melalui pelaksana PIPPK memberikan sosialisasi kepada masyarakat terkait program PIPPK

2. Pelaksana PIPPK mengajak secara Bersama RW, RT, PKK dan karang taruna melalui Musrembang

\section{DAFTAR PUSTAKA}

Alia, S., \& Maulana, J. (2019). Analisis Program Pembangunan dan Pemberdayaan Kewilayahan di Kota Bandung. Jurnal Ilmu Politik (POLITICON), 1(2), 209-220.

Bandung, B. P. S. K. (2015). Statistik Daerah Bandung Wetan 2015.

Haluana, K., \& Mustafa, W. (2016). Peran Kecamatan dalam Pembangunan Infrastruktur Jalan di Kecamatan Beringin Kabupaten Deli Serdang. Urnal Ilmu Pemerintahan Dan Sosial Politik UMA, 4(1), 11-22.

Hamidah, U. (2012). Peran Kecamatan Sebagai Perangkat Daerah Dalam Pelayanan Pertanahan (Studi pada Kecamatan Tanjung Karang Timur). Fiat Justitia Jurnal Ilmu Hukum, 5(2), 1-18.

Heri, Caesar, M. R., \& Zakaria, M. (2017). Peranan pemerintah daerah dalam pemberdayaan masyarakat. Jurnal Ilmiah "Politea" FISIP Universitas AlGhifari, 19(9), 21-34.

Muhyidin, Sumpena, D., \& Azis, A. (2017). Pemberdayaan Masyarakat Melalui Program Inovasi Pembangunan dan Pemberdayaan Kewilayahan. Tamkin: Jurnal Pengembangan Masyarakat Islam, 2(September),
59-79.

Pranarka, A.M.W. (1996). "Globalisasi Pember-dayaan dan Demokatisasi", dalam Onny S. Prijono dan A.M.V. Pranarka. 1996. Pemberdayaan: Konsep, Kebijakan,danImpIementasi. Jakarta CIDES.

Pranarka, A.M.W. dan Vidhiyandika Morljarto. 1996. "Pemberdayaan (Empower-ment)", dalam Onny S. Prijono dan A.M.V. Pranarka. 1996.

Peraturan Walikota Bandung Nomor 015 Tahun 2019 Tentang Pedoman Teknis Pelaksanaan Program Inovasi Pembangunan dan Pemberdayaan Kewilayahan. (2019).

Christian, Albert Januar.dkk. (2019). Implementasi Kebijakan Bandung ca'ang di Kabupaten Bandung Barat, 2-24.

Kertapradja, E. Koswara. (2007). Peranan

dan Kedudukan Camat dalam Sistem Pemerintahan Negara Kesatuan Republik Indonesia, Makalah disampaikan sebagai bahan Diskusi pada Forum Democratic Reform Support Program (DRSP).

Perubahan Kedua atas peraturan wali kota Bandung nomor 281 tahun 2015 tentang Pelaksanaan Program Inovasi Pembangunan dan Pemberdayaan kewilayahan kota Bandung. Retrieved from https://docplayer.info/74038507Wali-kota-bandung-denganrahmat-tuhan-yang-maha-esa.html

Prasatya, Sony Teguh. (2019). PIPPK, Otonomi

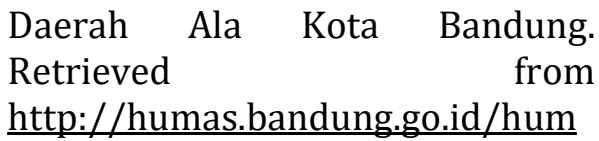




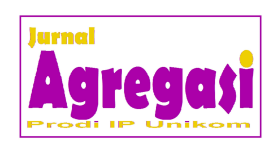

JURNAL AGREGASI

Jurnal Aksi Reformasi Government Dalam Demokrasi

Volume 7- Nomor 2, Desember 2019

DOI: $10.34010 /$ agregasi.v7i2.2314

Available online at: https://ojs.unikom.ac.id/index.php/agregasi

as/layanan/2019-04-25/pippkotonomi-daerah-ala-kota-bandung

Pangestu, Nawan. (2019). Kecamatan.

Retrieved

from

https://id.m.wikipedia.org/wiki/K

ecamatan

Supriatna Tjahya. (2000). Strategi

Pembangu-nan dan Kemiskinan. Jakarta:

Rineka Cipta. 